\title{
SMEs and the Innovation Management Process: A multi-level process conceptual framework
}

\author{
Angelo Dossou-Yovo and Christian Keen
}

\author{
"Ideas are like rabbits. You get a couple and learn how to handle them, and pretty soon \\ you have a dozen."
}

John Steinbeck

\begin{abstract}
The aim of this paper is to propose a conceptual framework to manage the innovation process in small businesses. It is based on research from 11 case studies in the Montreal software industry using contingency and resource dependency theories. This conceptual framework provides a view of the innovation process that differs from the linear approach often used in many studies to investigate innovation in small and medium sized businesses (SMEs). The linear approach considers the process as a set of activities that includes developing from one stage to another, while depending on the previous one. We conceptualize the innovation process in small businesses as an interactive process that involves a set of six subprocesses and several keys points of resources mobilization, which requires interacting with both internal and external business actors. Successful mobilization of innovation resources at all key points determines the success or failure of SMEs' innovation processes
\end{abstract}

\section{Introduction}

Innovation management in small businesses has been of interest to researchers for many years. One of the reasons is that innovation in small and medium sized enterprises (SMEs) occurs in a different way than in large companies. Small businesses face a resource challenge that differs from large companies. The ability to successfully manage the innovation process can be a particularly challenge for small businesses in high technology industries that need to innovate in order to survive. In the software industry, for example, research on innovation in small businesses tends to focus mainly on identifying resources (Romijn et al., 2002; Cho \& Linderman, 2020; Harel et al., 2020), and seems to consider the process as a "black box" that ignores how the type, needs, and availability of resources arise throughout the innovation process (Pustovrh et al., 2017; McDowell et al., 2018). Interest in conceptualizing the innovation process has received attention by researchers from multiple disciplines such as technology management, engineering, and strategy. However, the focus tends to be on the process of new product development, with the majority of works focused on identifying organizational and strategic success factors (Dunne et al., 2016; Kim et al., 2018; Bailetti et al., 2020).

Several conceptual frameworks (Eveleens, 2010; Bagno et al., 2017) have been suggested in the literature, however few of them approach innovation in SMEs as a process involving multiple actors and resources at the various stages of innovation. The purpose of this paper is therefore to suggest a framework that can be used by researchers to investigate the innovation process, as well as practitioners such as SME owners to manage it. We start in the following section by presenting what we mean by "innovation" and providing an overview of the research around SMEs' innovation. We suggest in section three a conceptual framework, which is further 


\section{SMEs and the Innovation Management Process: A multi-level process conceptual framework Angelo Dossou-Yovo and Christian Keen}

tested through a case study of the Montreal software industry that we present in section four. We then conclude with a discussion of the results and our suggestions for SME innovation managers.

\section{Innovation and SMEs}

In the third edition of the Organisation for Economic Co-operation and Development (OECD) "Oslo manual" (2005), "innovation" is defined as "the implementation of a new or significantly improved product (good or service), or process, a new marketing method, or a new organizational method in business practices, workplace organization or external relations". Nevertheless, according to the literature (see Table 1), innovations can be defined among several types. Innovation may thus refer to products, production processes, or organizations. Product innovation occurs when a new product or a significant improvement of an existing product is brought to the market. An innovation process occurs when there is an improvement of the production process or a modification of technologies.

What are the factors that make some SMEs more innovative than others? This question has been investigated by several studies that identified several possible factors related to the SME under consideration, the industry, and the market (De Jong \&Vermeulen, 2006; Ferradas et al., 2017; Arendt \& Grabowski, 2019). One important factor related to SME innovation is the network that can facilitate access to new markets, new knowledge, and risk sharing (Pittaway et al., 2004; Adner \& Feiler, 2019; Gupta et al., 2019). Romijn and Albaladejo (2002) suggested a classification of two groups of factors: external and internal. Internal factors include the training and previous experience of the founder, the professional qualifications of the staff, and activities that improve the knowledge base, such as research and development (R\&D), informal and formal learning, among others. External factors include the intensity of networking with a variety of actors and institutions, the advantages of geographical proximity to the network, as well as complementary institutional support. The classification of external and external factors was also used by Nizar et al. (2003), Caloghirou et al. (2004), and Vladimirov and Williams (2018) in their studies of the product innovation process in manufacturing, software, and hospitality industries. Internal factors include: company characteristics, strategies, structure, culture, and management team. External factors consist of: industry, region, networks, knowledge, public policy, and local culture.

Hausman (2005) introduced another factor in the client relationship as an actor in a SME network, which influences the capacity for innovation. By adopting a customer-oriented approach, it is thus possible to improve creativity and subsequently the ability to create new products. Indeed, social networks constitute a factor that increases the innovation performance of SMEs in the software industry (Fang, 2017; Belderbos et al., 2018). These networks provide access first to experts and knowledge, second to financial resources, and finally to intermediaries that can facilitate connections with other networks. This way SMEs can find new opportunities. Networks supply access to quality information, especially tacit knowledge for innovation when trust is established between the actors (Acheampong \& Hinson, 2019; Partanen et al., 2020). However, the value of knowledge available through these networks depends on the SME's absorptive capacity (Zhai et al., 2018; Limaj \& Bernroider, 2019). The concept of "absorptive capacity", introduced by Cohen and Levinthal (1994), refers to a company's ability to take advantage of knowledge from external sources, including the ability to assimilate and integrate it into a process for creating new products. This ability gets developed by the company through investments, such as covering the costs of staff training in new technologies.

Table 1. Types of innovations

\begin{tabular}{|c|c|}
\hline \begin{tabular}{|l} 
Authors \\
\end{tabular} & Types of innovation \\
\hline $\begin{array}{l}\text { Schumpeter \& Backhaus (2003) } \\
\text { Cantner \& Vannuccini (2018) } \\
\text { Malerba \& McKelvey (2020) }\end{array}$ & $\begin{array}{l}\text { - New products } \\
\text { - New production methods } \\
\text { - } \\
\text { - } \\
\text { Exploiting new ways of organizing } \\
\text { business }\end{array}$ \\
\hline $\begin{array}{l}\text { Edquist (2001) } \\
\text { Azar \& Ciabuschi (2017) } \\
\text { Markard (2020) }\end{array}$ & $\begin{array}{ll}\text { - } & \text { Technological innovation } \\
\text { - } & \text { Organizational innovation }\end{array}$ \\
\hline $\begin{array}{l}\text { Freeman \& Soete (1997) } \\
\text { Christensen et al. (2015) }\end{array}$ & $\begin{array}{ll}\text { - Incremental innovation } \\
\text { - Disruptive innovation }\end{array}$ \\
\hline
\end{tabular}




\section{SMEs and the Innovation Management Process: A multi-level process conceptual framework Angelo Dossou-Yovo and Christian Keen}

All of these studies showed that an SME's network contributes to enabling its access to resources. However, few authors have focused on the mechanisms that explain how SMEs use their network to mobilize innovation resources, innovate, and commercialize new products or services. Networks are comprised of actors that may be individuals or institutions (nodes) with weak and strong ties (Oskam et al., 2018; Vedres \& Cserpes, 2020). Weak ties often offer more valuable knowledge than strong ties, the latter wherein actors basically access the same sources of information. An intermediary may be contacted to fill a structural hole (Wu et al., 2020) in the network and play a bridging role that results in additional connections from other networks.

\section{Theoretical Conceptualization of SME Innovation Processes}

Innovation processes have been the subject of studies by researchers from multiple disciplines, such as technology management, engineering, and strategy. However, most works in this area have focused on identifying organizational factors, strategic factors, and other factors related to innovation that determine its success (Hart \& Baker, 1994; Pierre \& Fernandez, 2018; Usai et al, 2018). One of the most useful classifications was made by Rothwell (1992, 1994), who identified five generations of innovation process models: 1) technology push, 2) market pull, 3) coupling or research and development (R\&D) and marketing, 4) integrated models, 5) system integration and networking models. However, they can be regrouped into two categories: linear and network models. Examples of these models are presented in the following section, along with their limits as identified in the innovation management literature.

\subsection{Linear models}

A common feature of these models is their focus on new product development considered as a set of steps or sequential activities that includes developing from one stage to another while depending on the previous one. For example, Holt (2000) suggested a model with four steps as follows:

a) The production of new ideas (identifying a need and technology to meet this need);

b) The use of ideas (acquiring technology or development within the company);

c) The preparation phase, which consists of production planning and marketing the new product;

d) The implementation phase (introducing the product to market, production, and marketing).

Another approach is to consider the process of new product development as a group of seven main stages, each with specific activities. These stages are separated by evaluation points ("GO/KILL") where evaluations are made to decide whether to continue to the next step or not (Cooper \& Kleinschmidt, 1996). These seven stages are described as follows:

a) Defining the product idea through a process of idea generation that relies on sources of internal ideas ( $R \& D$ departments, sales, or marketing) and sources of external ideas (customers, research centers, suppliers, and government officials).

b) Preliminary assessment regarding the feasibility of the project based on a commercial and technical evaluation;

c) Defining and identifying the market, product benefits, attributes, and specifications;

d) Developing or producing a prototype;

e) Testing in the laboratory or with the client to identify faults and improvements;

f) Pre-commercialization;

g) Commercializing and large-scale production.

These linear models obscure the fact that the innovation process may be iterative or circular, since a basic idea may be revised when testing before marketing or market introduction. In addition, the fact that external actors intervene in the process is not highlighted in these models, especially when considering SMEs. Ultimately, these models do not seem especially applicable to the case of SMEs.

\subsection{The Multiple Convergent Processing Model}

Hart and Baker (1994) suggested the "multiple convergent processing" (MCP) model of new product development, which incorporates lessons learned from research on success factors for the developing new products. It also takes into account the interactions among various parties involved in the innovation process. 


\section{SMEs and the Innovation Management Process: A multi-level process conceptual framework Angelo Dossou-Yovo and Christian Keen}

In this model, the authors present innovation as a series of activities that involve information gathering and evaluation activities. Throughout the process, different points and types of evaluations relate to market or product functions with multiple points of convergence. The process also involves focal points with moments where certain activities are performed simultaneously by different parties (actors in the network, different departments). These focal points are used to exchange information between the different parties and integrate the information exchanged. The actors involved are from both internal and external networks. The internal network is comprised of different departments or project teams, while the external network includes other companies, R\&D institutions (universities, laboratories), and customers. The MCP model's authors approach innovation with a dynamic perspective that includes a network of internal and external actors.

\subsection{A proposal of a multi-level process model}

Linear models see innovation as a set of sequential activities that integrate a very limited number of actors, essentially internal actors such as organizational functions. They therefore ignore the learning process and interactions with external actors, the role of entrepreneurs, and resource mobilization. The integrated and networking models add the learning process and more external actors in innovation, but still limit the role of the entrepreneur and the resource mobilization process is not explicit. Most of these 2 types of models lean more toward a corporate model of innovation, instead of an entrepreneurship model of innovation.

The model put forward here builds on the combination of contingency theory and innovation management (Tidd, 2001; Ahmed et al., 2020) along with resource dependency theory (Pfeffer \& Salancik, 1978; Ghosh, 2019). Following contingency theory, this article suggests that organizational structure should adapt to both internal and external factors. Thus, processes should also be change depending the most efficient structure given the contextual factors. Thus, firms require several strategies depending on the context (Brandon-Jones et al., 2014). We consider the contingency approach especially in relation to characteristics of innovation that we consider as dynamic and interactive. In addition, we assume that SMEs are innovation resource-dependent and that innovation occurs through an interactive process with a series of activities and resource-acquisition points by analogy to the focal points from Hart and Baker's (1994) model. The resource acquisitions points are critical for accessing innovation resources (see Figure 1).

At the resource acquisition points, SMEs must connect with external actors to access the resources needed for innovation to move ahead. For example, R\&D activities require funding or access to a research laboratory. If SMEs have constrained resources, funding can then only be external (public or private sources). We thus posit that SMEs' innovation depends on external resources in its environment, and that therefore they need to build a network that enables them connect with actors that hold the resources needed for them to complete the innovation process. For this, we propose the following six subprocesses:

1) Idea generation and selection

This first subprocess involves interactions with internal and external actors that will generate the inputs that will be transformed into outputs, such as new ideas and tools, or selection criteria for the new idea that will result in further projects.

2) Transformation

Transformation involves interactions with actors that will generate inputs such as activities undertaken to create outputs like new products (for example, prototype or final product).

\section{3) Learning}

Learning involves interactions with internal and external actors that will generate inputs such as new knowledge, which can be transformed into outputs such as a repository of new tools or routines for innovating.

4) Resource mobilization

Resource mobilization is mostly performed by entrepreneurs that involve interactions with actors that will generate new contacts to create outputs such as social capital and a network that will help to access external innovation resources.

5) Commercialization

Commercialization involves all interactions with internal and external actors that will generate inputs such as alliances and partnerships that will be transformed into outputs, such as a new market or sales growth.

6) Coordination

Coordination involves the interactions that will 


\section{SMEs and the Innovation Management Process: A multi-level process conceptual framework Angelo Dossou-Yovo and Christian Keen}

\begin{abstract}
facilitate the identification of relevant actors and integrate their interventions throughout the innovation process.
\end{abstract}

In the following section, we make a case study of the Montreal Software to test our multi-level process model.

\section{Case study: the Montreal software industry}

\section{a. Overview of the Montreal software industry}

The Montreal software industry is a subsector of the information and communication technology (ICT) industry in Quebec, Canada. It is an important pillar of the Canadian and Quebec economies according to its contribution to gross domestic product (GDP), job creation rate, and impacts on others sectors that benefit from applications made by the software industry. The software industry includes multimedia and telecommunications services.

In this research, we were particularly interested in companies that produce software for multimedia application. These companies are involved in an industry that requires constant innovation, and therefore requires much $R \& D$.

The multimedia software applications industry includes companies that develop software for video games, 3D animations, websites, search portals, interactive advertising, transactional web sites, simulations, and interactive imagery. According to Ministère de l'Économie et de l'Innovation du Quebec, in 2019 the information and communications technologies sector employed close to 137,000 workers and generated revenues of close to $\$ 32.5$ billion, in addition to being the source of approximately $\$ 1.7$ billion in annual research and development (R\&D) investment.

This sector is also characterized by a strong presence of SMEs, which have an average of 18 employees and make up a significant concentration in Montreal. The Quebec ICT sector has built an international reputation with the creation of special effects software for Hollywood productions. Large companies in this industry include Ubisoft and Electronic Arts.

\section{b. Methodology}

We used a qualitative research method with multiple cases studies (Yin, 1984, 2003; Miles \& Huberman, 2003). We chose an in-depth analysis of the phenomenon, according to an inductive approach to better understand our research subject. We chose to study multiple cases so as to identify differences and constants to better understand the research problem (Miles \& Huberman, 2003). Our goal was to understand SMEs' innovation process from our sample so that we might design a framework for managing the innovation process. The data come from several different sources, which we believe is key to obtaining the information needed to study the cases (Halinen \& Törnroos, 2005).

These sources include: 1) data from the literature and websites of companies, 2) field notes, 3) semi-structured interviews with company CEOs. The interviews were conducted, transcribed, and analyzed with the qualitative software Nvivo 8. In this research, we focussed on the innovation process in eleven (11) small businesses in the Montreal software industry which were selected after an exploratory study that targeted 83 small businesses. We used open-ended questions during the interviews that were organized around the following themes: A general description of the business, type of innovations, innovation intensity, and a description of the innovation process, including actors, interactions, challenges, and resources. The interviewees and several characteristics of SMEs in this study are presented in Table 2 below.

\section{c. Findings \\ Product innovation}

The results show that the SMEs in our study differ in terms of the type of innovation introduced in the market. Most of the SMEs introduced a new product except two. One introduced a service innovation and the second a process innovation (see Table 3).

We found that there were three critical steps in the innovation process where external resources were needed to perform related activities (see Figure 1). These three steps are conceptualizing a technological solution, $\mathrm{R} \& \mathrm{D}$, and marketing. During idea development, new innovation ideas were the most valuable resources for conceptualizing a technological solution. The resources needed for $R \& D$ are knowledge, competences, and financial support. Finally, the resources needed for commercialization include financial support, knowledge, and new markets.

\section{Critical steps during the innovation process}

While innovating, these three main stages involve the intervention of external actors to acquire necessary resources (see Figure 2). The client is the most important actor that helps especially during the technological conceptualization. This actor helps to 


\section{SMEs and the Innovation Management Process: A multi-level process conceptual framework Angelo Dossou-Yovo and Christian Keen}

Table 2. List of SMEs and characteristics

\begin{tabular}{|c|c|c|c|c|c|}
\hline SME & $\begin{array}{l}\text { Services } \\
\text { offered }\end{array}$ & $\begin{array}{l}\text { Actual } \\
\text { market }\end{array}$ & $\begin{array}{l}\text { Number of } \\
\text { employees }\end{array}$ & $\begin{array}{c}\text { Age } \\
\text { (years) }\end{array}$ & Interviewees \\
\hline E1 & $\begin{array}{c}\text { Software } \\
\text { development } \\
\text { businesses }\end{array}$ & Canada & 35 & 12 & Chairman \\
\hline E2 & $\begin{array}{c}\text { Quality } \\
\text { monitoring } \\
\text { software }\end{array}$ & $\begin{array}{l}\text { Canada and } \\
\text { International }\end{array}$ & 400 & 12 & Chairman \\
\hline E3 & Video games & $\begin{array}{l}\text { Canada and } \\
\text { International }\end{array}$ & 148 & 15 & CEO \\
\hline E4 & $\begin{array}{l}\text { Software for } \\
\text { website } \\
\text { development }\end{array}$ & $\begin{array}{l}\text { Canada and } \\
\text { International }\end{array}$ & 5 & 25 & Chairman \\
\hline E5 & Video games & $\begin{array}{l}\text { Canada and } \\
\text { International }\end{array}$ & 500 & 10 & $\mathrm{COO}$ \\
\hline E6 & $\begin{array}{l}\text { Software for } \\
\text { information } \\
\text { management }\end{array}$ & $\begin{array}{l}\text { Canada and } \\
\text { International }\end{array}$ & 95 & 21 & Chairman \\
\hline E7 & $\begin{array}{l}\text { Software for } \\
\text { developers }\end{array}$ & $\begin{array}{l}\text { Canada and } \\
\text { International }\end{array}$ & 2 & 14 & Chairman \\
\hline E8 & $\begin{array}{c}\text { Multimedia } \\
\text { software }\end{array}$ & Quebec & 8 & 15 & Chairman \\
\hline E9 & Video games & $\begin{array}{l}\text { Canada and } \\
\text { International }\end{array}$ & 6 & 5 & Chairman \\
\hline E10 & $\begin{array}{c}\text { Software } \\
\text { development } \\
\text { for document } \\
\text { editing }\end{array}$ & $\begin{array}{l}\text { Canada and } \\
\text { International }\end{array}$ & 12 & 10 & Chairman \\
\hline E11 & $\begin{array}{l}\text { Software for } \\
\text { email } \\
\text { management }\end{array}$ & Canada & 10 & 7 & Chairman \\
\hline
\end{tabular}

identify and validate the functions that the final product should perform to satisfy users. R\&D activities acquire resources from the client and other actors, such as associations, virtual networks, universities, research centers, educational institutions, universities, government organizations, consulting firms, incubators, and suppliers. Commercialization activities with the actors involve: associations, government programs, government organizations, incubators, and suppliers.

\section{The importance of external factor during the innovation} process

Our results show that SME innovation processes depend on external resources available in their environment, at least during critical development stages. The actors cited in the study were already part of the SME network. SMEs, represented by the founder, were in connection with most actors through networking activities organized by associations. Therefore, we can conclude that a dependency relationship exists between SMEs and their innovation network of actors that play a bridging role to acquire either directly the necessary innovation resources, or indirectly by helping to connect with other actors (see Figure 3).

Our findings show multiple external actors with different roles involved in interactions around innovation processes. During the idea generation and selection stage interactions are mostly with the clients. For example, SME's E3 and E4 used feedback from 


\section{SMEs and the Innovation Management Process: A multi-level process conceptual framework Angelo Dossou-Yovo and Christian Keen}

Table 3. Type of innovations

\begin{tabular}{|l|l|l|l|}
\hline \multicolumn{1}{|c|}{ SME } & \multicolumn{1}{|c|}{ Type of innovation } & \multicolumn{1}{|c|}{ SME } & \multicolumn{1}{c|}{$\begin{array}{c}\text { Type of } \\
\text { Innovation }\end{array}$} \\
\hline E1 & Product innovation & E8 & $\begin{array}{l}\text { Product } \\
\text { innovation }\end{array}$ \\
\hline E2 & Service innovation & E9 & $\begin{array}{l}\text { Product } \\
\text { innovation }\end{array}$ \\
\hline E3 & Product innovation & E10 & $\begin{array}{l}\text { Product } \\
\text { innovation }\end{array}$ \\
\hline E4 & Product innovation & E11 & $\begin{array}{l}\text { Product } \\
\text { innovation }\end{array}$ \\
\hline E5 & Process innovation & & \\
\hline E6 & Product innovation & & \\
\hline E7 & Product innovation & & \\
\cline { 1 - 2 } & & &
\end{tabular}

clients to generate and select new ideas:

"We have suggestions from clients each year. We receive them and keep them somewhere and when we finish a project and [are] about to start another, we meet and put everything on the table" (CEO, E4).

"Feedback is constant. We have a friendly relationship with our customers, which means that we have their feedback very quickly: listen, your product does not work, can you improve it?" (CEO, E3).

The transformation process follows the first stage and consists of several outputs that develop upon the preliminary ideas generated, as illustrated by the CEO of SME4.

"The process begins with a generation of ideas that meet the market needs during a meeting between engineers. Thereafter, a list of product characteristics and priorities is determined. This information helps to launch the research and development $(R \& D)$ project that leads into a product that will undergo several tests. The first group of tests is performed by the R\&D team, and

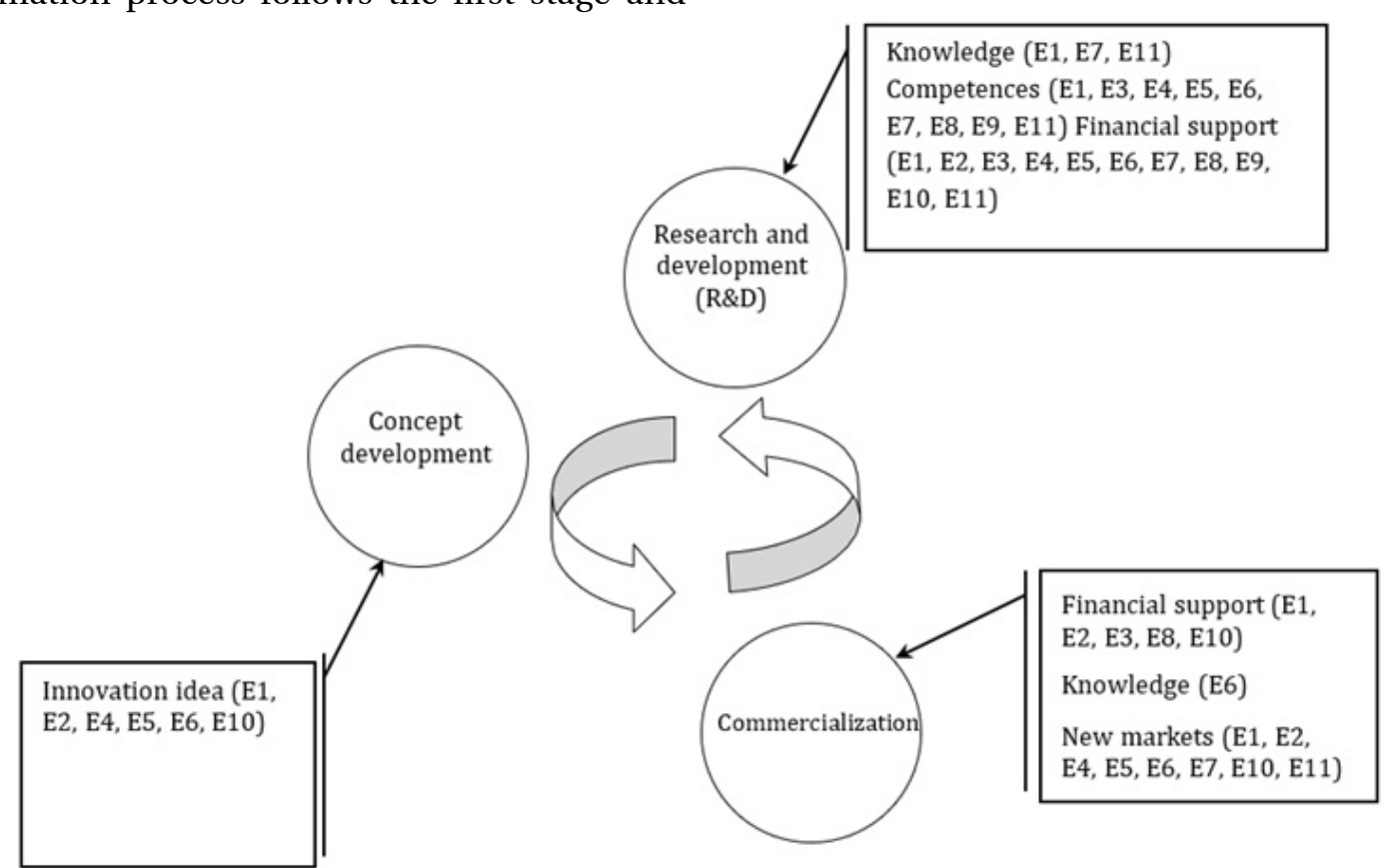

Figure 1. Critical stages of the process and resources 


\section{SMEs and the Innovation Management Process: A multi-level process conceptual framework Angelo Dossou-Yovo and Christian Keen}

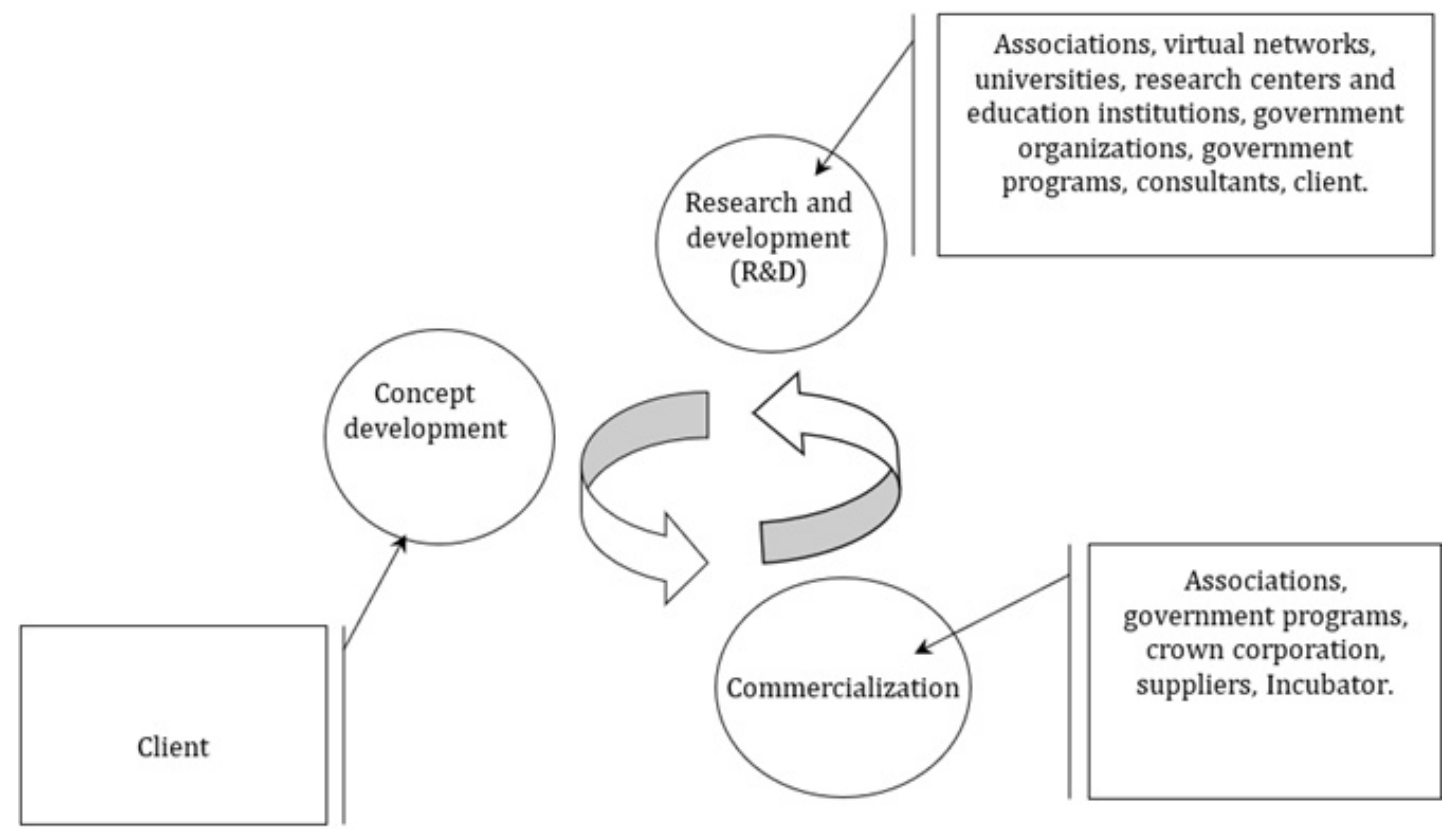

Figure 2. Critical stages and actors involved in resource acquisition

the second one is done with external collaborators. A third group of tests is done with the client as we send the product to a limited number of clients that will provide us with information to improve the product before starting a large-scale commercialization" (CEO, E4).

As stated in our model, the learning process also involves several actors. For example, R\&D specialists in E1 use online communities and forums to gain new knowledge. E2 brought changes in its product based on the CEO's own experience with suppliers in France.

"It is more with the underground networks: groups, online communities, forums. Our R\&D specialists use frequently these networks.... You will have to contribute before you receive" (CEO, E1).

"The initial concept for multimedia products and video games was acquired in France. But we noticed that there were too many bugs, it was often poorly translated or not translated or partially translated, so I thought of developing a new method" (CEO, E2).

While mobilizing resources, the entrepreneur's role of is very important. E3 uses its contact with universities to get new trainees, while E4 goes through its partners in Europe. These partnerships would not possible if the entrepreneur did not invest time and resources to find them and build a trustworthy relationship.

"It's been years [that] we are dealing with Cegep, University of Montreal, UQAM a little less because it is less adapted to our needs.... I have contacts with instructors who can suggest trainees to me, so it works very well with universities" (CEO, E3).

"We have editors who make boxes in Europe, Spain, and Germany. We have partners in e-commerce, Internet marketing specialists who take care of the indexing, referencing" (CEO, E4).

The commercialization process also involves interactions. For example, E2 used the international missions organized by its association to travel to China and make contacts to expand its market. E3 uses industry events like game summits to promote its products.

"It allowed me to meet directly with Chinese officials, to visit two cities and make good contacts to start development in China" (CEO, E2).

"The game summit will take place in November this year; we will send several of our employees ... and maybe this year we will have a booth to promote our products" (CEO, E3). 


\section{SMEs and the Innovation Management Process: A multi-level process conceptual framework Angelo Dossou-Yovo and Christian Keen}

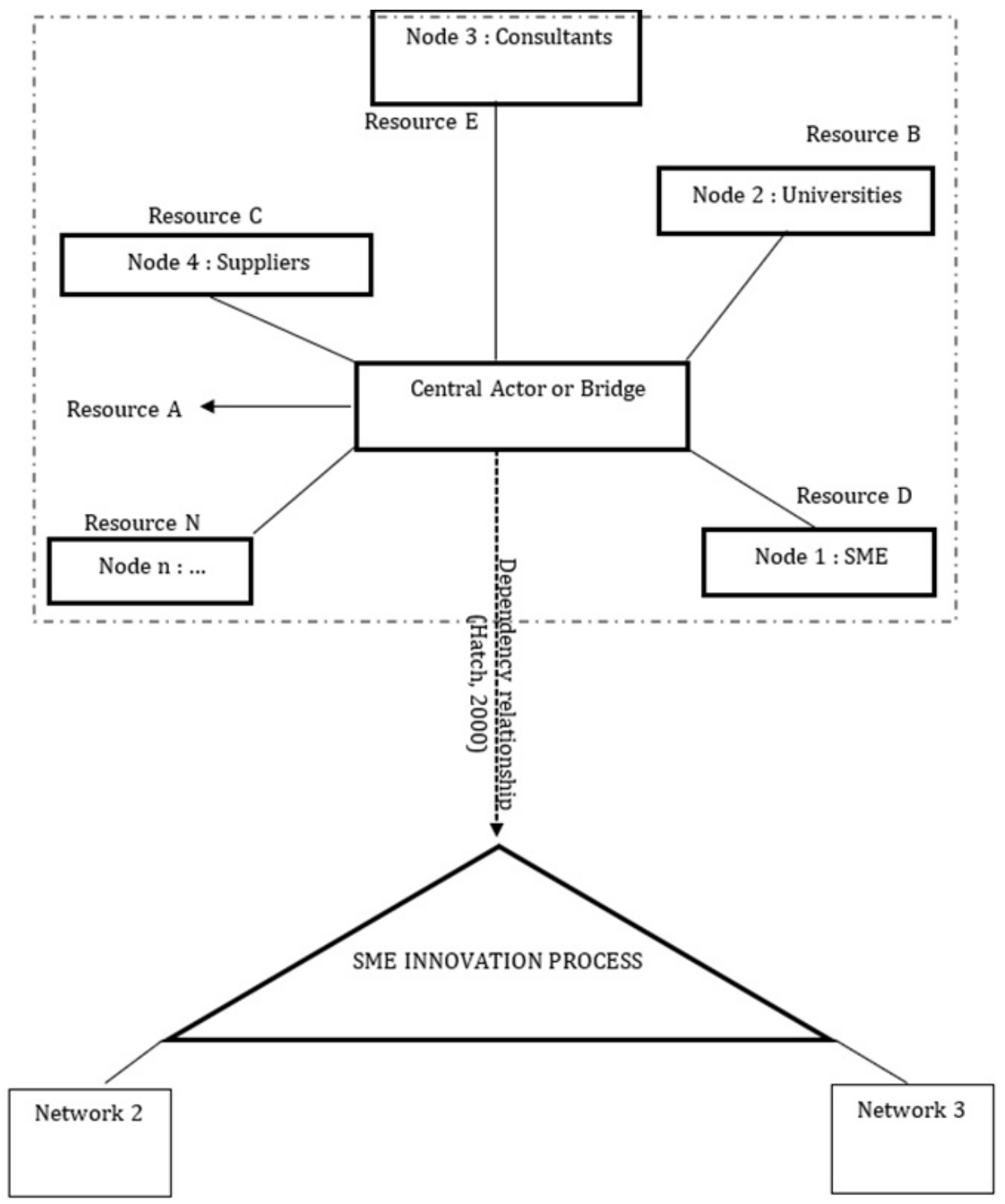

Figure 3. Innovation process and network of actors for innovation resource

\section{Conclusions and Implications for SME Innovation Management}

In this paper, we suggested a framework that is comprised of different subprocesses that make up the overall innovation process. Our empirical study showed that the innovation process in small businesses can be viewed through the lens of different subprocess that consider the data collected from SMEs.

We believe our framework is a useful tool for SMEs innovation managers as it offers a novel approach to manage interactions with multiple actors and stimulate resource mobilization through focus on specific subprocesses, as opposed to the whole innovation process at once. Further studies could improve the framework by looking at differences between sectors. In addition, our results suggested that the innovation network an SME belongs to can benefit the innovation process. This is particularly the case for SMEs with resource constraints. It is also consistent with other studies that have shown firms tend to network to innovate, and also that a diversity of actors benefits innovation (Scott et al., 2019; Brunetta et al., 2020). Our results contribute to the existing research on innovation in small businesses by offering an additional approach to conceptualizing innovation through contingency theory and the resource dependency approach. Our results show also that innovation processes are highly interactive and involve important actors that help SMEs 


\section{SMEs and the Innovation Management Process: A multi-level process conceptual framework Angelo Dossou-Yovo and Christian Keen}

to innovate. Successful acquisition of innovation resources at all key points of the innovation process (critical stages) depends on the network and type of actors.

SME innovation managers or company founders, particularly in high technology industries, should therefore focus on building an innovation network where key actors or bridges for innovation get included. They also should pay particular attention to the critical innovation stages where resources are available only through external actors. Hence, it is important to identify and connect with external actors that can help during focus points on innovation. The network also needs to be built based on the requirements for each subprocess. Finally, a monitoring system should be put in place around each subprocess to ensure proper oversight of activities, resources, interactions, and both internal and external actors involved.

\section{References}

Acheampong, G., \& Hinson, R.E. 2019. Benefitting from alter resources: network diffusion and SME survival. Journal of Small Business \& Entrepreneurship, 31(2): 141-158.

Adner, R., \& Feiler, D. 2019. Interdependence, perception, and investment choices: An experimental approach to decision making in innovation ecosystems. Organization Science, 30(1): 109-125.

Ahmed, W., Najmi, A., \& Ikram, M. 2020. Steering firm performance through innovative capabilities: A contingency approach to innovation management. Technology in Society, 63(November): 101385.

Arendt, L., \& Grabowski, W. 2019. The role of firm-level factors and regional innovation capabilities for Polish SMEs. Journal of Entrepreneurship, Management and Innovation, 15(3): 11-45.

Azar, G., \& Ciabuschi, F. 2017. Organizational innovation, technological innovation, and export performance: The effects of innovation radicalness and extensiveness. International Business Review, 26(2): 324-336.

Bailetti, T., Tanev, S., \& Keen, C. 2020. What makes value propositions distinct and valuable to new companies committed to scale rapidly? Technology Innovation Management Review, 10(6).

DOI: http://doi.org/10.22215/timreview/1365

Belderbos, R., Gilsing, V., Lokshin, B., Carree, M., \& Sastre, J.F. 2018. The antecedents of new R\&D collaborations with different partner types: On the dynamics of past $R \& D$ collaboration and innovative performance. Long Range Planning, 51(2): 285-302.

Brunetta, F., Marchegiani, L., \& Peruffo, E. 2020. When birds of a feather don't flock together: Diversity and innovation outcomes in international $R \& D$ collaborations. Journal of Business Research, 114: 436445.

Cooper, R.G., \& Kleinschmidt, E.J. 1996. Winning businesses in product development: The critical success factors. Research-Technology Management, 39(4): 18-29.

Bagno, R.B., Salerno, M.S., \& da Silva, D.O. 2017. Models with graphical representation for innovation management: a literature review. $R \& D$ Management, 47(4): 637-653.

Brandon-Jones, E., Squire, B., Autry, C.W., \& Petersen, K. 2014. A contingent resource based perspective of supply chain resilience and robustness. J. Supply Chain Manag. 50 (3): 55-73.

Cho, Y.S., \& Linderman, K. 2020. Resource-Based Product and Process Innovation Model: Theory Development and Empirical Validation. Sustainability, 12(3): 913. https:// doi.org/10.3390/su12030913

Christensen, C.M., Raynor, M.E., \& McDonald, R. 2015. What is disruptive innovation. Harvard Business Review, 93(12): 44-53. 


\section{SMEs and the Innovation Management Process: A multi-level process conceptual framework Angelo Dossou-Yovo and Christian Keen}

Caloghirou, Y., Kastelli, I., \& Tsakanikas, A. 2004. Internal capabilities and external knowledge sources: complements or substitutes for innovative performance? Technovation, 24(1): 29-39.

Cantner, U., \& Vannuccini, S. 2018. Elements of a Schumpeterian catalytic research and innovation policy. Industrial and Corporate Change, 27(5): 833850.

Cohen, W.M., \& Levinthal, D.A. 1994. Fortune favors the prepared firm. Management Science, 40(2): 227-251.

De Jong, J.P.J., \&. Vermeulen, P. 2006. Determinants of product innovation in small firms: A comparison across industries. International Small Business Journal, 24(6): 587-609.

Dunne, T.C., Aaron, J.R., McDowell, W.C., Urban, D.J., \& Geho, P.R. 2016. The impact of leadership on small business innovativeness. Journal of Business Research, 69(11): 4876-4881.

Edquist, C. 2001. The Systems of Innovation approach and innovation policy: An account of the state of the art. Lead paper presented at the DRUID Conference, Aalborg. Accessed on July 26th, 2010: http://www.tema.liu.se/tema-t/sirp/chaed.htm

Eveleens, C. 2010. Innovation Management: a literature review of innovation process models and their implications. Science, 800: 900-916.

Fang, S.C., Wang, M.C., \& Chen, P.C. 2017. The influence of knowledge networks on a firm's innovative performance. Journal of Management and Organization, 23(1): 22. DOI: 10.1017/jmo.2016.32

Freeman, C. \& Soete, L. 2020. The Economics of Industrial Innovation, third edition. Cambridge, MIT Press.

Ferradas, M.I.R., Tanco, J.A.A., \& Sandulli, F. 2017. Relevant factors of innovation contests for SMEs. Business Process Management Journal, 23(6): 11961215.

https://doi.org/10.1108/BPMJ-10-2016-0201

Gupta, R., Mejia, C., \& Kajikawa, Y. 2019. Business, innovation and digital ecosystems landscape survey and knowledge cross sharing. Technological Forecasting and Social Change, 147: 100-109.

Halinen, A., \& Törnroos, J.Å. 2005. Using case methods in the study of contemporary business networks. Journal of Business Research, 58(9): 1285-1297.

Harel, R., Schwartz, D., \& Kaufmann, D. 2020. Organizational culture processes for promoting innovation in small businesses. EuroMed Journal of Business.

https://doi.org/10.1108/EMJB-03-2020-0027.

Hart, S. \& Baker, M. 1994. The Multiple Convergent Processing Model of New Product Development. International Marketing Review, 11(1): 77-92.

Hatch, M. 2000. Théories des Organisations: de l'intérêt des perspectives multiples. De Boeck, Bruxelles.
Hausman, A. 2005. Innovativeness among small businesses: theory and propositions for future Research. Industrial Marketing Management, 34(8): 773-82.

Holt, K. 2000. Product Innovation Management, 3rd edition. U.K.: Butterworths.

Kim, B., Kim, H., \& Jeon, Y. 2018. Critical success factors of a design startup business. Sustainability, 10(9): 2981.

Limaj, E., \& Bernroider, E.W. 2019. The roles of absorptive capacity and cultural balance for exploratory and exploitative innovation in SMEs. Journal of Business Research, 94: 137-153.

Malerba, F., \& McKelvey, M. 2020. Knowledge-intensive innovative entrepreneurship integrating Schumpeter, evolutionary economics, and innovation systems. Small Business Economics, 54(2): 503-522.

Markard, J. 2020. The life cycle of technological innovation systems. Technological Forecasting and Social Change, 153: 119407. https://doi.org/10.1016/j.techfore.2018.07.045

McDowell, W.C., Peake, W.O., Coder, L., \& Harris, M.L. 2018. Building small firm performance through intellectual capital development: Exploring innovation as the "black box". Journal of Business Research, 88: 321-327.

Miles, M.B., \& Huberman M.A. 2003. Analyse des données qualitatives. 2éd. Paris : De Boeck.

OECD. 2005. Oslo Manual: Guidelines for Collecting and Interpreting Innovation Data, 3rd Edition.

Oskam, I., Bossink, B., \& de Man, A.P. 2018. The interaction between network ties and business modeling: Case studies of sustainability-oriented innovations. Journal of Cleaner Production, 177: 555566.

Partanen, J., Kauppila, O.P., Sepulveda, F., \& Gabrielsson, M. 2020. Turning strategic network resources into performance: The mediating role of network identity of small and medium sized enterprises. Strategic Entrepreneurship Journal, 14(2): 178-197.

Patton, M.Q. 2001. Qualitative Research \& Evaluation Methods: Integrating theory and practice. Sage publications.

Pfeffer, J. \& Salancik, G. 1978. The External Control of Organizations: A Resource-dependence Perspective. New York: Harper \& Row.

Pierre, A., \& Fernandez, A.S. 2018. Going deeper into SMEs' innovation capacity: An empirical exploration of innovation capacity factors. Journal of Innovation Economics Management, (1): 139-181.

Pittaway, L., Robertson, M., Kamal, M., Denyer, M., \& Neely, A. 2004. Networking and innovation: A systematic review of the evidence. International Journal of Management Review, 5/6(3\&4): 137-168. 


\section{SMEs and the Innovation Management Process: A multi-level process conceptual framework Angelo Dossou-Yovo and Christian Keen}

Pustovrh, A., Jaklic, M., Martin, S.A. and Raškovic, M. 2017. Antecedents and determinants of high-tech SMEs' commercialisation enablers: opening the black box of open innovation practices. Economic ResearchEkonomska Istraživanja 30(1): 1033-1056.

Romijn, H. \& Albaladejo, M. 2002. Determinants of innovation capability in small electronics and software firms in Southeast England. Research Policy, 31(7): 1053- 1067.

Rothwell, R. 1992. Successful industrial innovation: critical factors for the 1990s. $R \& D$ Management, 22: 221-240.

https://doi.org/10.1111/j.1467-9310.1992.tb00812.x

Rothwell, R. 1994, Towards the Fifth generation Innovation Process, International Marketing Review, Vol. 11 No. 1: 7-31.

Schumpeter, J., \& Backhaus, U. 2003. The Theory of Economic Development. In Joseph Alois Schumpeter. Springer, Boston, MA: 61-116.

Scott, S., Hughes, M., \& Kraus, S. 2019. Developing relationships in innovation clusters. Entrepreneurship \& Regional Development, 31(1-2): 22-45.

Tidd, J. 2001. Innovation Management in Context: environment, organization and performance. International Journal of Management Reviews, 3(3): 169-183.

https://doi.org/10.1111/1468-2370.00062

Usai, A., Scuotto, V., Murray, A., Fiano, F., \& Dezi, L. 2018. Do entrepreneurial knowledge and innovative attitude overcome "imperfections" in the innovation process? Insights from SMEs in the UK and Italy. Journal of Knowledge Management, 22(8): 1637-1654. https://doi.org/10.1108/JKM-01-2018-0035

Vedres, B., \& Cserpes, T. 2020. Open Ties and Deep Success. In Academy of Management Proceedings. Briarcliff Manor, NY 10510: Academy of Management, Vol. 2020, No. 1: 18879.

Vladimirov, Z., \& Williams, A. 2018. Hotel innovations and performance. The mediating role of staff related innovations. Tourism management perspectives. 28: 166-178.

Wu, H., Gu, X., Zhao, Y., \& Liu, W. 2020. Research on the Relationship between Structural Hole Location, Knowledge Management and Cooperative Innovation Performance in Artificial Intelligence. Knowledge Management Research \& Practice: 1-10.

https://doi.org/10.1080/14778238.2020.1813642

Yin, R.K. 2003. Case study research, design and methods, 3rd ed. Newbury Park: Sage Publications.

Yin, R.K. 1984. Case study research. Design and methods. Beverly Hills: Sage Publications.

Zhai, Y. M., Sun, W. Q., Tsai, S. B., Wang, Z., Zhao, Y., \& Chen, Q. 2018. An empirical study on entrepreneurial orientation, absorptive capacity, and SMEs' innovation performance: A sustainable perspective. Sustainability, 10(2): 314.

https://doi.org/10.3390/su10020314

\section{About the Authors}

Dr. Angelo Dossou-Yovo is Associate Professor in the Department of International Studies at York University (Toronto, Canada) where he teaches Management and Entrepreneurship in the dual degree program in International Studies and Business Administration, a program jointly offered with emLyon Business School (France). His research interests focus on the processes of opportunity recognition, growth and innovation in small and medium sized businesses in the information technology industry as well as innovation and entrepreneurial ecosystems.

Christian Keen, $\mathrm{PhD}$ is an Assistant Professor at the Département de Management, Université Laval, Canada. Christian has an extensive research and working experience in Europe, Latin America, and North America. Before joining Université Laval, Dr. Keen was Director Graduate Program in Finance at Universidad ORT Uruguay and member of the Department of Marketing \& Management at University of Southern Denmark. His professional experience includes being member of several the Board of Directors of private companies and NGOs. He teaches graduate and undergraduate courses in international entrepreneurship, entrepreneurship, and international business. His research interests are in the areas of international entrepreneurship, entrepreneurship, emerging economies, and rapidly growing firms. Christian is a member of the editorial board of the International Journal of Entrepreneurship and Small Business, and associated editor of TIM Review and European Journal of Family Business. He has presented his research in several international conferences such as AIB, AOM, EIBA, and has also published papers in those areas.

Citation: Dossou-Yovo, Angelo and Keen, Christian. SMEs and the Innovation Management Process: A multi-level process conceptual framework. Technology Innovation Management Review, 11(1): 22-33. http://doi.org/10.22215/timreview/1414

Keywords: Innovation process, small business, Innovation, Innovation management 